\title{
PROCEDURAL STATUS OF THE INJURED PERSON IN THE LEGAL ORDER OF THE SLOVAK REPUBLIC IN COMPARISON WITH ITS LEGAL REGULATION IN THE CZECH REPUBLIC ${ }^{1}$
}

\section{PROCESNÉ POSTAVENIE POŠKODENÉHO V PRÁVNOM PORIADKU SLOVENSKEJ REPUBLIKY V KOMPARÁCII $S$ ČESKOU REPUBLIKOU}

\author{
Martin Štrkolec \\ University of Pavol Jozef Šafárik in Košice, Faculty of Law
}

https://doi.org/10.33542/SIC2020-1-09

\begin{abstract}
The author examines the procedural position of the injured person during the entire course of criminal proceedings, with respect to both the pre-trial and trial stage. In connection with the procedural status of the injured person, the author also analyses the possibilities of the participation of the injured person or his/her representative in procedural acts performed by law enforcement authorities and courts in order to fulfil their own subject of criminal proceedings, which also involves deciding on the injured person's compensation claim for damage caused to him as a result of the given crime. At the beginning of the article, the author presents the historical aspects of the procedural status of the injured person in the Czech Republic and the Slovak Republic, which form a basis for presenting a comparative perspective on the status of the injured person in the two legal systems. At the end of the article, the author formulates his own de lege ferenda proposals in the context of the Slovak Republic.
\end{abstract}

\begin{abstract}
ABSTRAKT
Autor sa v článku zaoberá procesným postavením poškodeného v priebehu celého trestného konania, a to tak s ohl'adom na jeho predsúdnu, ako aj súdnu čast'. V súvislosti s procesným postavením poškodeného autor v článku analyzuje taktiež možnosti účasti poškodeného, respektive jeho splnomocnenca na procesných úkonoch vykonávaných orgánmi činnými $v$ trestnom konaní a súdmi za účelom naplnenia vlastného predmetu trestného konania, pod ktorý možno nepochybne zaradit' rozhodovanie o nároku poškodeného na náhradu škody, ktorá mu v príčinnej súvislosti s trestným činom vznikla. V úvode článku sa autor venuje taktiež historickým aspektom procesného postavenia poškodeného v Českej a Slovenskej republike, na podklade ktorých sa v priereze celého článku venuje taktiež komparatívnemu pohl'adu na poškodeného $v$ oboch právnych poriadkoch. Vo vztahu $k$ Slovenskej republike autor v závere článku formuluje vlastné návrhy de lege ferenda.
\end{abstract}

\footnotetext{
The presented contribution was prepared with the support of and as an output of the research project APVV-16-0362 "Privatisation of criminal law - substantive, procedural, criminological, organisational and technical aspects."
} 


\section{INTRODUCTION}

Act No. 301/2005 Coll. the Criminal Proceedings Code as amended by later legislation (hereinafter the "Criminal Proceedings Code") came into effect on 1 January 2006. In its provision of Article 1, it defines the subject of the Criminal Proceedings Code as follows: "The Criminal Proceedings Code lays down the procedure followed by law enforcement authorities and courts to ensure that crimes are adequately investigated and that their perpetrators are justly punished, while respecting the basic rights and freedoms of natural and legal persons." This quoted provision implies not just to the subject of the Act but also its purpose, i.e. adequate investigation of crimes and just punishment for their perpetrators with particular emphasis on respect for the fundamental rights and freedoms of natural and legal persons by law enforcement authorities and courts.

What is also apparent from the provision of Article 1 of the Criminal Proceedings Code is an important interpretation rule according to which law enforcement authorities and courts are obliged to proceed in such a way as to fulfil its purpose, i.e. adequate investigation of crimes and just punishment for their perpetrators, while respecting the fundamental rights and freedoms of natural and legal persons contained in the Constitution of the Slovak Republic, the Charter of Fundamental Rights and Freedoms, and the Criminal Proceedings Code and the international agreements by which the Slovak Republic is bound, whose ultimate purpose is to ensure a just process as an inherent principle of the rule of law model.

The provision of Article 1 (1) of Act No. 141/1961 Coll. on Criminal Court Proceedings (Criminal Proceedings Code) as amended by later legislation is still valid and effective in the Czech Republic (hereinafter the "Czech Criminal Proceedings Code"), defines the purpose of the Czech Criminal Proceedings Code, i.e. to lay down the procedure followed by "law enforcement authorities to ensure that crimes are adequately investigated and that their perpetrators are justly punished under the law. The proceedings shall at the same time contribute to reinforcing lawfulness, to preventing criminal activities, to educating the public in the spirit of thoroughly abiding by the law and the rules of civil coexistence and the conscientious fulfilment of obligations towards the state and society." This purpose of the Czech Criminal Proceedings Code is identical to the purpose defined in Act No. 141/1961 Coll. on Criminal Court Proceedings (Criminal Proceedings Code) as amended by later legislation, which was also valid and effective in the Slovak Republic until 31 December 2005.

Act No. 45/2013 Coll. on Victims of Criminal Offences and on the amendment to certain acts was adopted in the Czech Republic in 2013. During the legislative process, it was proposed that the words "and that injured persons achieve the satisfaction of their claims" be added to the provision of Article 1 (1) of the Czech Criminal Proceedings Code in order to amend the legislative wording of the Czech Criminal Proceedings Code in such a way that the purpose of criminal proceedings is not just adequate investigation of crimes and just punishment for perpetrators but also the satisfaction of the injured person's legitimate claims for damage compensation, which is to emphasise the restorative aspect of criminal proceedings. According to P. Šámal, it is, however, necessary to respect the basic purpose of criminal proceedings mentioned above. ${ }^{2}$ It is mainly for this reason that the protection of the rights of injured persons received its legislative formulation in the provision of Article 2 (15) of the Czech Criminal Proceedings Code, as part of a normative definition of the basic principles of the Czech Criminal Proceedings code. ${ }^{3}$ Unlike the purpose of criminal proceedings, which

\footnotetext{
For more details, see: SLÁVIKOVÁ, T.: Účel trestného konania - je záujem o poškodeného sekundárny?. In: Bulletin slovenskej advokácie. 2015, vol. 21, issue 10, p. 19.

3 For more details, see: ŠÁMAL, P. et. al.: Trestní řád I. § 1 až 156. Komentáŕ. 7th edition Prague. C. H. Beck, 2013, p. 56.
} 
should be fulfilled in each individual proceeding, the main principle of criminal proceedings is always considered for the given particular case and assessed with respect to other basic principles of criminal proceedings on the basis of their mutual balancing.

Act No. 274/2017 Coll. on Victims of Crime as amended by later legislation was adopted in the Slovak Republic in 2017 (hereinafter the "Act on Victims"). The Act on Victims was prepared mainly on the basis of the policy statement of the Government of the Slovak Republic for the 2016-2020 period in its Crime Policy and Prisons section. The Act on Victims completed the transposition of Directive 2012/29/EU of the European Parliament and of the Council of 25 October 2012 establishing minimum standards on the rights, support and protection of victims of crime, and replacing Council Framework Decision 2001/220/JHA, into the legal system of the Slovak Republic, and its adoption was intended to comprehensively establish the rights of victims, compensation for victims of violent crime and the mechanism for supporting entities providing assistance to victims of crimes, which was intended to strengthen the status of victims of crimes in criminal proceedings. ${ }^{4}$

The Act on Victims also introduced a new basic principle of criminal proceedings into the Slovak Republic's legislation by supplementing the provision of Article 2 (21) to the Criminal Proceedings Code with the following wording: "Law enforcement authorities and the court are obliged to allow the injured person, throughout criminal proceedings, to fully exercise his/her rights, which he/she needs to be duly, appropriately and comprehensibly informed about. Criminal proceedings shall proceed with due consideration for the injured person. It is necessary to consider his/her personal situation and immediate needs, age, gender, any disability and maturity, and to fully respect his/her physical, mental and moral integrity. This is without prejudice to the provisions of the special act on the rights of victims of crimes."

Based on what has been said so far, it can be stated that the protection of the rights of the injured person in the Czech Republic and the Slovak Republic is not the primary purpose of their respective procedural codes defined in the provision of Article 1 of the Criminal Proceedings Code and the provision of Article 1 (1) of the Czech Criminal Proceedings Code. Despite this, what needs to be appreciated is the fact that the protection of the rights of the injured person has been incorporated into the basic principles of criminal proceedings in the Czech Republic and the Slovak Republic since 2013 and 2018 respectively, whose application and interpretation role in view of the principles of criminal law is undeniable.

\section{Historical development of the legal status of the injured person in the Czech Republic and the Slovak Republic}

Criminal Proceedings Code No. XXXIII/1896 applied in the Slovak Republic, including Subcarpathian Ruthenia, during the Austria-Hungary period. This law distinguished the concepts of 'injured person', 'private party', 'main plaintiff' and 'substitute plaintiff'. To qualify as an injured person under this law, it was sufficient to be threatened by a crime - this was the so-called ideal injured person. A private party was an injured person who exercised his/her rights in criminal proceedings, as well as any legal representative of such a person who engaged in criminal proceedings. A substitute plaintiff was an injured person who took over the role of prosecution from the prosecutor if the prosecutor declined to file charges in a particular case. Another possible situation was when the injured person acted as the main plaintiff, where he/she could file a lawsuit as a private entity without the need for a prior request from a prosecutor for filing the lawsuit. However, this model of complete privatisation of prosecution

4 For more details, see: The explanatory report for the Act on Victims is available at: https://www.slov-lex.sk/legislativneprocesy/-/SK/dokumenty/LP-2017-551. 
was not unconditional. The prosecutor could take over prosecution at any point during proceedings initiated by a private person and represent it from the position of a public authority if this was deemed to be in the public interest. ${ }^{5}$

Act No. 87/1950 Coll. on Criminal Court Proceedings (Criminal Proceedings Code) (hereinafter "Act No. 87/1950 Coll.") provides that "A person who suffers damage due to a crime (injured person) shall be given an opportunity to exercise his/her claims arising from a crime and to make motions during the trial and appeal proceedings. "Under the provision of Article 53 (4) of Act No. 87/1950 Coll., an injured person's representative was "entitled to participate in all of the acts in which the injured person may participate... " The injured person's right to view files was enshrined in the provision of Article 66 (1) of Act No. 87/1950 Coll. Under the provision of Article 89 (3) of Act No. 87/1950 Coll., an injured person had the right to be "informed, if possible," about the discontinuance of criminal proceedings. This wording did not allow an injured person to challenge the prosecutor's decision to discontinue criminal proceedings. Whereas under the provision of Article 151 of Act No. 87/1950 Coll., an injured person had the right to put questions during the trial to the persons being heard, the given procedural code did not include the right of an injured person to make a final speech. Relatively detailed provisions regarding court decisions on an injured person's claims arising from a crime were included in the provision of Article 164 (1) of Act No. 87/1950 Coll., whose states that: "If the court finds the defendant guilty, it shall make a decision on the injured person's claims arising from the crime, provided that the injured person requested it prior to the court's final deliberations and provided that a decision about the claim was not made during proceedings in civil legal matters. "Under the provisions of Article 164 (2)(3) of Act No. 87/1950 Coll.: "If the exact extent of a claim can not be determined without significant delays, the court shall grant it up to the amount which it is proven to have reached and which it deems adequate, and the court shall refer the injured person to proceedings in civil legal matters regarding the remaining part of the claim. The court shall also refer the injured person to proceedings in civil legal matters in cases where it is not possible to determine even the adequate amount of the claim without significant delays". The list of injured person's entitlements in Act No. 87/1950 Coll. was in fact completed by the provision of Article 173 (1c), under which an injured person could challenge a sentence in an appeal "on the grounds of an incorrect statement about his/her claims arising from a crime. " Compared to the legislation from the period of Austria-Hungary, Act No. 87/1950 Coll. introduced public prosecution as the only form of criminal prosecution, without allowing the right of private or subsidiary prosecution.

Act No. 141/1961 Coll. on Criminal Court Proceedings (Criminal Proceedings Code) was then adopted in the Slovak Republic (hereinafter "Act No. 141/1961 Coll."), which amended by later legislation is still valid and effective in the Czech Republic. Under Act No. 141/1961 Coll., an injured person was understood as a person "who suffered bodily injury, property damage, moral or other damage as a result of a crime”. The provision of Article 43 of Act No. 141/1961 Coll. also contained a general list of injured persons' procedural rights, such as the right to make motions for the taking of additional evidence, the right to view files, the right to participate in the trial and public hearings regarding appeals, and the right to give a final speech before the end of the proceedings. The individual aspects of a compensation claim made by an injured person were provided for in the provisions of Article 43 (2)(3) of Act No. 141/1961 Coll., according to which: "An injured person who is legally entitled to

5 For more details, see: RŮŽIČKA, M, PÚRY, F., ZEZULOVÁ, J.: Poškozený a adhézní řízení v České republice. Prague: C.H.Beck, 2007. p. 98 et seq. 
compensation in a claim against the defendant for damage caused by a crime is also entitled to submit a motion asking the court to impose, in its sentence, an obligation on the defendant to compensate this damage. This motion shall be made no later than during the trial before the taking of evidence begins (Article 206 (2)). The motion shall clearly state the reason for the claim and the amount of the damage claim. Under (2), such a motion can also be made by the prosecutor if this is required for the sake of protecting the public interest, socialist organisations or workers, particularly if the crime caused damage to property under socialist ownership." The provision of Article 47 et seq. of Act No. 141/1961 Coll. establish the entitlement of an injured person to damage compensation and the provision of Article 50 establish the procedural status of an injured person's representative, who could, under the provision of Article 51, participate in "all of the acts in which the injured person can participate." Similarly to the individual provisions of Act No. 87/1950 Coll., Act No. 141/1961 Coll. granted injured persons the right to view files and the right to put questions to the persons being heard during the trial. Under the provision of Article 177 (3) of Act No. 141/1960 Coll. a decision to discontinue criminal proceedings had to be delivered to the injured person, but the injured person was not granted the right to use a legal remedy against such a decision. The provision of Article 216 (2) of this Act did not grant injured persons the right to make a final speech after the taking of evidence during the trial. Court decisions on claims exercised by injured persons were provided for in the provisions of Articles 228 and 229 of Act No. 141/1961 Coll. Under the provision of Article 228 of this Act, if the court convicted the defendant for a crime resulting in property damage caused to another person, the sentence typically imposed on the defendant an obligation to compensate such damage, provided that the claim was exercised in due time. The provision of Article 229 of Act No. 141/1961 Coll. provided for the possibility to refer the injured person to proceedings on civil legal matters, provided that after the taking of evidence, there were insufficient grounds for imposing an obligation to compensate, or if a decision to impose such an obligation required further taking of evidence beyond what is necessary for the purposes of criminal prosecution, causing significant delays, then the court referred the defendant to proceedings on civil legal matters or to proceedings before another competent authority. The court proceeded in the same way if it, for any reason, only granted a part of the injured person's claim, or if it acquitted the defendant. The amendment of Act No. 141/1961 Coll. by Act No. 57/1965 Coll. granted an injured person who was also the person reporting the crime the right to file a complaint against a police officer's decision to suspend the matter, which de iure began to expand the rights of injured persons in relation to criminal proceedings that were different from the right to compensation and decisions on claims. $^{6}$

\section{Legal definition of the injured person and his/her procedural rights with emphasis on the pre-trial stage of criminal proceedings}

Under the provision of Article 46 (1) of the Criminal Proceedings Code: "An injured person is a person who suffered bodily damage, property damage, moral or other damage as a result of a crime, or whose other legally protected rights or freedoms were infringed or threatened as a result of a crime." Since the Criminal Proceedings Code became effective, its individual provisions regarding the procedural status of injured persons have been amended in response to the requirements of everyday legal practice in the Slovak Republic and in response to the Slovak Republic's obligations arising from its European Union membership. The procedural rights of injured persons during the entire course of criminal proceedings are

6 For more details, see: JURIŠOVÁ, K.: Poškodený v predsúdnom konaní. Prague: Leges, 2017. p. 47 et seq. 
generally stated in the provision of Article $46(1)(2)$ of the Criminal Proceedings Code, according to which: ,,The injured person has the right, in cases specified in this Act, to state whether he/she agrees with the initiation of criminal proceedings, to submit motions for the taking of evidence or its supplementation, present evidence, view and examine files, participate in the trial and in public hearings on appeals and guilt and punishment agreements." Act No. 397/2015 Coll., which, for the purposes of the Criminal Code, establish the list of substances with anabolic or other hormonal effects, amending and supplementing certain acts, incorporated into the provision of Article 48 of the Criminal Proceedings Code the right of an injured person to be accompanied by a trusted person in the procedural acts of criminal proceedings. In addition to other procedural entitlements arising for the injured person from the individual provisions of the Criminal Proceedings Code, the injured person may, under the provision of Article 46 (3) of the Criminal Proceedings Code, submit a motion asking the court to impose on the defendant, in its sentence, an obligation to compensate any damage caused to him by a crime. The injured shall submit such a motion by the end of any investigation or accelerated investigation. The motion shall clearly state the reason for the claim and the amount of the damage claim.

It follows from the previous paragraph that a claim for damage caused to the injured person as a result of a crime shall be exercised in criminal proceedings duly and in a timely manner. "If this motion was submitted after the end of the required period, it can not be considered in criminal proceedings. In such a case the court shall decide not to admit such a person to the trial as an injured person with a damage compensation claim."7 The requirement that the injured person exercise his/her damage claim within a certain period makes the de lege lata law problematic in some cases. The injured person's opportunity to exercise his/her damage claim in a timely manner is significantly limited particularly in cases where the law enforcement authorities undertake, in preparatory proceedings, the so-called super fast investigation in accordance with the provision of Article 204 of the Criminal Proceedings Code. Under this provision of the Criminal Proceedings Code, if a prosecutor receives a file for a person arrested as a suspect while committing a crime punishable, under the law, by a prison sentence of up to five years, the prosecutor shall, immediately after the arrest or after any obstacle to the person's immediate arrest ceases to exist within 24 hours of committing the offence (and the prosecutor does not release the person), hand over the person and the file to the court and bring charges within 48 hours of the arrest. The 48 -hour period within which, upon the application of the provision of Article 204 of the Criminal Proceedings Code, law enforcement authorities are obliged to hand over a person arrested as a suspect while committing a crime, together with his/her file, and bring charges is simply too short for any injured persons to exercise their claim for damage resulting from the crime.

A judge who, upon the application of the provision of Article 204 of the Criminal Proceedings Code, proceeds according to a special procedure for preparatory proceedings after receiving charges typically uses the relatively common method of judgement involving a criminal order under the provision of Article 353 of the Criminal Proceedings Code, i.e. without ordering a trial and without an opportunity for the injured person to participate in court proceedings as a party. In these cases, a claim for damage compensation made by an injured person in preparatory proceedings for those objective reasons mentioned above can not be exercised in a timely manner (i.e. by the end of a super accelerated investigation under the provision of Article 204 of the Criminal Proceedings Code), so a decision on the obligation to compensate damage will not be included in such a judgement consisting of a criminal order. Injured per-

ČENTÉŠ, J.: Uplatnenie nároku na náhradu škody v adhéznom konaní. In: Justičná revue, 60, 2008, issue 12, p. 1692. 
sons in such cases are not even deemed entitled to submit a statement of opposition to such a judgement. ${ }^{8}$ Even if the prosecutor or the defendant did submit a statement of opposition to such a criminal order, the injured person would not be able to effectively demand compensation in the sentencing judgement at the trial for damage resulting from a crime, as his/her motion was not submitted within the 48-hour period specified by the Criminal Proceedings Code for a super fast investigation.

Therefore, the provision of Article 46 (3) of the Criminal Proceedings Code needs to be amended de lege ferenda by drawing inspiration from the historical wording of Act No. 141/1961 Coll., i.e. the criminal procedure code effective in the Slovak Republic before the current Criminal Proceedings Code came into effect, which provided in its provision of Article 43 (2) that an injured person who is legally entitled to compensation in a claim against the defendant for damage caused by a crime is also entitled to submit a motion asking the court to impose, in its sentence, an obligation on the defendant to compensate this damage. According to the previous normative provision, the injured person was obliged to submit such a motion no later than at the trial before the taking of evidence commenced. This opinion is also supported by the current wording of Article 43 (3) of the Czech Criminal Proceedings Code, still valid and effective in the Czech Republic, according to which: "The injured person is also entitled to submit a motion asking the court to impose, in its sentencing judgement, an obligation to financially compensate material or non-material damage caused to the injured person as a result of a crime, or to return any amount of unjustified enrichment of the defendant at the expense of the injured person. Such a motion shall be submitted no later than at the trial before the taking of evidence commences (...)." "The aforementioned need for amending the provision of Article 46 (3) of the Criminal Proceedings Code is also supported by the views of other authors in the field of criminal law. ${ }^{10}$

Another relatively problematic area of the performance of injured persons' procedural rights at the pre-trial stage of criminal proceedings is the potential possibility for injured persons to participate, in person or through a representative, in the individual investigation acts performed by law enforcement authorities within preparatory proceedings, particularly the possibility to participate in the hearing of the defendant, witnesses or experts at this stage of criminal proceedings. This is because this right of injured persons or their representatives is not explicitly enshrined in the provisions of Article 46 et seq. of the Criminal Proceedings Code. The provision of Article 53 (1) of the Criminal Proceedings Code provides for the possibility for an injured person to be represented by a representative in criminal proceedings, the provision of Article 53 (2) of the Criminal Proceedings Code specifies in more detail the procedural competence of an injured person's representative, and the provision of Article 54 of the Criminal Proceedings Code lists the individual procedural entitlements of an injured person's representative, which include the right of a representative to participate in all acts in which the injured person may participate. So the explicit wording of the Criminal Proceedings Code disqualifies the injured person and his/her representative, during the course of investigation, from participation in procedural acts other than the hearing of the the defendant in the

8 Under the provision of Article 355 (2) of the Criminal Proceedings Code: "The injured person may submit a statement of opposition to a decision granting a damage claim; if the injured person submitted a statement of opposition, the criminal order is annulled in the damage claim decision. A single judge refers the injured person to a civil proceeding or to a proceeding before other competent authority. The judge shall proceed in the same manner even if other authorised person submits a statement of opposition to the damage claim decision." If a damage claim is not granted to the injured person in a criminal order, he/she is not entitled to submit a statement of opposition to the criminal order.

9 For more details, see: ŠÁMAL, P. et. al.: Trestní řád I. § 1- 156. Komentár̆. 7th edition Prague: C.H.Beck, 2013. p. 506 et seq.

10 For more details, see: IVOR, J. et. al.: Optimalizácia prípravného konania trestného. Prague: Leges, 2017, p. 579. 
procedural position of a witness and accessing the investigation file after the end of the investigation. Moreover, the Criminal Proceedings Code does not contain a provision that would allow the injured person or his/her representative to put questions to the persons being heard in the way that the provision of Article 213 (1) of the Criminal Proceedings Code allows the defendant and his/her representative to do so. For these reasons, it is difficult, in the application practice of law enforcement authorities, to produce arguments for the participation of the injured person or his/her representative in the hearing of the defendant, witnesses or experts. Possible arguments invoke the principle of contradictoriness, equality of parties and equality of arms arising from the right to a fair trial guaranteed by the European Convention for the Protection of Human Rights and Fundamental Freedoms and by means of the decisionmaking of the European Court of Human Rights. ${ }^{11}$ Although the requirements of equality of arms within the right to a fair trial apply mainly to defendants, we are of the view that these guarantees should also apply to injured persons and to pursuing their legitimate interests in criminal proceedings. We are also of the view that the general guarantee of equality of arms, due to the concept of Slovakia's criminal proceedings, ${ }^{12}$ should also be applied to their pretrial stage.

De lege ferenda, it would be appropriate to draw inspiration from the legislation in the Czech Republic. Under the provision of Article 51 (2) of the Czech Criminal Proceedings Code: "The representative of the injured person and the person involved is entitled, from the beginning of criminal proceedings, to participate in investigation acts aimed at revealing facts important for exercising the rights of the persons he/she represents, and their outcome may be used as evidence in court proceedings, unless his/her participation threatens the purpose of criminal proceedings or if the act can not be postponed until delivering a notification about it. He/she may put questions to the persons being heard, but only after the police authority ends the hearing and allows him/her to speak. He/she may raise objections to the performance of the acts any time during the proceedings." This provision was incorporated into the Czech Criminal Proceedings Code by its amendment by Act. 45/2013 Coll. on Victims of Crimes as amended by later legislation, which granted equal rights to the defendant's lawyer and the injured person's representative with respect to the possibility to attend and actively participate in investigation acts in preparatory proceedings. By amending this provision of the Czech Criminal Proceedings Code, the Czech legislator clearly sought to strengthen the status of the injured person in criminal proceedings and to ensure the overall contradictoriness of criminal proceedings already at the preparatory proceedings stage. ${ }^{13}$ In view of this, the fact that deserves criticism at this point is that the author of the Slovak Act on Victims of Crimes did not include in the amendment of the Criminal Proceedings Code this explicit possibility considered by the Czech legislator on a similar occasion, despite the application-related prob-

11 For more details, see for example: SVÁK, J.: Ochrana l’udských práv (z pohl’adu judikatúry a doktríny štrasburských orgánov ochrany práv) II. rozšírené vydanie. Bratislava: EUROKÓDEX, 2006. p. 446 et seq.

12 For more details, see for example: The provision of Article 263 (3) of the Criminal Proceedings Code, according to which: "Statements by a co-defendant or witness may be read even when the hearing was conducted in accordance with the provisions of this act and such a person has died or is missing, or can not be reached due to being permanently resident overseas or because his/her whereabouts are unknown, or is suffering from a condition that prevents his/her hearing permanently or for a longer period, or if the person fails to attend a hearing, without an excuse, even after being repeatedly summoned by the court; in the case of a witness statement where it could be reasonably assumed, when the statement was given in preparatory proceedings, that the witness would not be able to attend the trial, such a statement can only be read if the defendant and his/her lawyer (if he/she has one) were duly informed of this act."

13 For more details, see: ŠÁMAL, P. et. al.: Trestní řád I. § 1 - 156. Komentár. 7th edition Prague: C.H.Beck, 2013. p. 584 et seq. 
lems with the (im)possibility for the injured person and his/her representative to attend and actively participate in all investigation acts. ${ }^{14}$

\section{Status of the injured person in court proceedings with a focus on his/her procedural rights in the trial}

What deserves special attention in terms of application practice with respect to the trial part of criminal proceedings is the cooperation of the injured person or his/her representative in the taking of evidence in court proceedings, particularly in relation to their possibility to comment on evidence presented at the trial, the possibility to present personal evidence at the trial, as well as the length and form of final speeches made by these persons. We should first characterise the current de lege lata state regarding specific areas. Under the provision of Article 271 (1) of the Criminal Proceedings Code: "After presenting each evidence, it is necessary to ask the injured person and the person involved whether they wish to comment on it, and their comments should be recorded in court records. "; according to the provision of Article 272 (1) of the Criminal Proceedings Code: "After the end of a hearing with questions from the prosecutor, the defendant, his/her representative or the presiding judge, the defendant's legal representative or representative, the person involved or his/her authorised person may, with the consent of the presiding judge and within the scope of the exercised rights, put questions to the persons being heard when the senate members have no further questions"; and, finally, according to Article 274 (2) of the Criminal Proceedings Code: "Final speeches by the prosecutor and a representative of a civil association are followed by a speech by the injured person, the person involved, the defendant's representative and the defendant. If the injured person or the person involved has a representative, only the representative shall speak. If necessary, the presiding judge shall determine the order of the speeches by the authorised persons. However, the defendant's lawyer and the defendant always speak last; the representative of a civil association, the injured person and the person involved or their representative may only speak within the scope of the exercised rights."

As it was mentioned above, the Criminal Proceedings Code in its provision of Article 271 (1) provides for the right of the defendant, the injured person and the person involved to be asked after each presented evidence whether they wish to comment on it, and should record each comment in court records. If the defendant is not present at the trial when a certain piece of evidence is presented, and is therefore unable to immediately comment on it, the court shall allow him/her to do so upon returning to the courtroom. For this reason the presiding judge shall inform him/her about the part of the proceedings undertaken during his/her absence. The defendant's absence from the courtroom, his/her return, the information provided about the proceedings undertaken in his/her absence and the defendant's comments shall be recorded in the record of the trial. This provision of the Criminal Proceedings Code is an expression of the principles of contradictoriness and equality of arms implied in the more broadly formulated right of the persons involved to a fair trial, and is therefore a logical consequence of the fact that evidence is presented mainly by the parties and with their active cooperation. ${ }^{15}$

However, there are certain rare cases in the application practice of courts where the court allows the injured person, after evidence is presented at the trial, to comment on the evidence, but will deny this procedural right to his/her representative on the grounds that the literal wording of the provision of Article 271 (1) of the Criminal Proceedings Code does not grant it

14 For more details, see: The explanatory report for the Act on Victims is available at: https://www.slov-lex.sk/legislativneprocesy/-/SK/dokumenty/LP-2017-551.

15 For more details, see: ČENTÉS̆, J. et. al.: Trestný poriadok. Vel'ký komentár. Bratislava: EUROKÓDEX. 2014 , p. 551. 
to him/her. We are of the view that such procedural steps by courts do not comply with the purpose of this provision, as the injured person's representative is typically a attorney who, in accordance with the provisions of Article 18 (1)(2) of Act No. 586/2003 Coll. as amended by later legislation, is obliged to protect and promote the rights and interests of the client, and to use, in the interest of the client, all available means he deems beneficial. In view of the fact that the injured person is typically a person without legal qualifications, the procedural steps being criticised here are a substantial interference with the rights and legitimate interests of the injured person, who struggles to grasp all the substantive and procedural circumstances that are important for achieving a favourable result in criminal proceedings, i.e. achieving a sentencing judgement which grants the claim for damage resulting from a crime. Moreover, the injured person's representative exercises the relevant rights arising from the Criminal Proceedings Code on behalf of the injured person. ${ }^{16}$ For this reason, it is appropriate to grant the injured person's representative, analogously to the defendant's lawyer, all the procedural rights in specific cases that are autonomously available to the defendant.

In light of what was stated in the preceding paragraphs of the article, we should also take a critical view of the de lege lata provisions of the Criminal Proceedings Code regarding the possibility for the injured person or his/her representative to put questions to the persons being heard at the trial and to make a final speech merely within the "scope of the exercised rights", as the explicit wording of the Criminal Proceedings Code indicates in the provisions of Articles 272 (1) and 274 (2). These provisions of the Criminal Proceedings Code create a certain degree of legal uncertainty meaning that some courts restrict the exercise of these rights by the injured person and his/her representative to questions related to the given damage claim and do not permit questions or a factual and legal assessment of the presented evidence in a final speech related to other substantial matters.

According to the general theory of criminal procedural law, the purpose of criminal proceedings includes determination of objective facts and subsequent decisions by law enforcement authorities and courts on whether the given act did take place; whether the act that took place was a criminal offence; whether it was committed by a specific criminally liable person; on imposing a punishment or a protective measure, and also decisions on the injured person's duly and timely exercised damage claim. It can now be established that a possible favourable decision on the injured person's duly and timely exercised damage claim essentially depends on those decisions related to the substance of the matter, which are of a substantive character and consist in holding specific perpetrators of crimes criminally responsible. The possibility for the injured person or his/her representative to put questions to the persons being heard at the trial and to make a final speech "within the scope of th exercised rights" should, for the reasons stated in this paragraph, be interpreted to mean that the given procedural right shall be granted to the injured person or his/her representative within the scope of any questions that may, in line with the principle of free assessment of evidence, the principle of adequate investigation of facts without reasonable doubts, and other principles of criminal proceedings, have a significant effect on the factual and legal assessment of the specific criminal matter.

De lege ferenda, it would be appropriate in the this context to draw inspiration from the legislation in the Czech Republic, whose provision of Article 215 (1) of the Czech Criminal Proceedings Code provides that: "The state representative, the defendant, his/her lawyer and guardian, the injured person and their representatives may, with the consent of the presiding judge, put questions to the persons being heard, typically when the presiding judge and the

16 For more details, see: ČENTÉŠ, J. et. al.: Trestný poriadok. Vel'ký komentár. Bratislava: EUROKÓDEX. 2014, p. 182. 
senate members have no further questions", and, also, according to Article 216 (2) of the Czech Criminal Proceedings Code: "The state representative's final speech shall be followed by a speech by the injured person, the person involved, the defendant's lawyer or the defendant. If the injured person has a representative, the representative shall speak. If necessary, the presiding judge shall determine the order of the speeches by the authorised persons after the state representative's final speech. The defendant's lawyer or the defendant always speak last."; as the quoted provisions of the Czech de lege lata legislation do not limit the exercise of the given procedural rights by the injured person or his/her representative to mere "within the scope of the exercised rights"“, but instead allow them im argumentum e silentio to exercise them within the scope of the entire subject of the specific criminal matter.

\section{CONCLUSION}

As it follows from the body of the presented article, de lege ferenda, the Slovak legislation regarding the procedural status of the injured person and his/her representative should draw inspiration from the Czech legislation, particularly in relation to the possibility for these persons to participate in all investigation acts in preparatory proceedings, whose outcome may be used as evidence in court proceedings, then in relation to the time period for the injured person to exercise a damage claim, and in relation to the strengthening of the rights of these persons in court proceedings, particularly in the course of the trial, to ensure that the injured person's rights correspond to the right to a fair trial guaranteed mainly by he European Convention for the Protection of Human Rights and Fundamental Freedoms and by means of the decision-making of the European Court of Human Rights and by the Constitution of the Slovak Republic.

In terms of the legislation applying to criminal proceedings and the procedural rights of the individual entities of criminal proceedings, the Slovak Republic and the Czech Republic share a common historical basis consisting mainly of Act No. 141/1961 Coll. on Criminal Court Proceedings (Criminal Proceedings Code), which became effective in both countries on 1 January 1962. Despite the overall recodification of the Slovak criminal procedure by means of the Criminal Proceedings Code effective from 1 January 2006, it can be stated that the Czech criminal policy related to the procedural status of the injured person and his/her representative has moved forward much faster in recent years and in a more comprehensive and efficient manner.

To give an example, both legal systems have seen the adoption of a special act on victims of crime in the past six years, amending certain provisions on the criminal procedure codes, including the procedural status of the injured person and his/her representative. Act No. 45/2013 on Victims of Crimes and on Amending Certain Acts, as well as the Slovak Act on Victims of Crimes, introduced a new basic principle of criminal proceedings, i.e. the principle of the protection of the rights of the injured person throughout the course of criminal proceedings. The Czech legislator, however, used this opportunity to strengthen the procedural rights on injured persons more convincingly, as, in addition to incorporating this basic principle of criminal proceedings into the Czech Criminal Proceedings Code, he also amended its other provisions in a way which ultimately strengthens the injured person's rights, especially in preparatory proceedings.

However, we should not overlook the interpretation role of the newly-introduced basic princile of criminal proceedings defined in the provision of Article 2 (21) of the Criminal Proceedings Code, according to which in a country with material rule of law, which the Slovak Republic is considered to be, every provision of the Criminal Proceedings Code needs to be interpreted with respect to the purpose for which this basic principle is enshrined in the legal 
order of the Slovak Republic. "In a country with the rule of law, which represents as its integral parts, inter alia, principles such as legal certainty and justice (the principle of material rule of law), which can be reliably inferred from Article 1 of the Constitution, particular emphasis is placed on the protection of the rights that form the subject thereof. It is the duty of all state authorities to ensure that they can be exercised by entities to which they have been granted." 17 According to the explanatory report for the act on victims, "the basic principles of criminal proceedings are extended to include a new principle aimed at protecting the rights of the injured person and strengthening his/her status during the course of criminal proceedings. This principle shall be considered and applied in interpreting the individual provisions of this Act." $" 18$ It can be concluded based on this that even the legislation applying to the procedural status of the injured person in criminal proceedings needs to be interpreted in accordance with the newly-introduced basic principle of criminal proceedings establishing special protection of injured persons, so even with the unsatisfactory current state of de lege lata, it is necessary to grant these persons, throughout criminal proceedings, all rights which arise for them in a country with material rule of law directly from the Constitution of the Slovak Republic and which fully comply with the country's current criminal policy.

\section{KLUUČOVÉ SLOVÁ}

poškodený, škoda, náhrada škody, splnomocnenec, práva poškodeného, práva splnomocnenca, zásada ochrany práv poškodených.

\section{KEY WORDS}

injured person, damage, damages, representative, rights of the injured person, rights of the representative, principle of protecting the rights of injured persons.

\section{BIBLIOGRAPHY}

1. Č́ENTÉŠS, J. et. al.: Trestný poriadok. Vel'ký komentár. Bratislava: EUROKÓDEX. 2014.

2. ČENTÉŠ, J. Uplatnenie nároku na náhradu škody v adhéznom konaní. In: Justičná revue, 60, 2008, vol. 12.

3. IVOR, J., POLÁK, P., ZÁHORA, J.: Trestné právo procesné I. Bratislava: Wolters Kluwer. 2017.

4. IVOR, J. et. al.: Optimalizácia prípravného konania trestného. Prague: Leges, 2017.

5. JURIŠOVÁ, K.: Poškodený v predsúdnom konaní. Prague: Leges, 2017.

6. RŮŽIČKA, M, PÚRY, F., ZEZULOVÁ, J.: Poškozený a adhézní řízení v České republice. Prague: C.H.Beck, 2007.

7. SLÁVIKOVÁ, T.: Účel trestného konania - je záujem o poškodeného sekundárny?. In: Bulletin slovenskej advokácie. 2015, vol. 21, p. 10.

8. SVÁK, J.: Ochrana l'udských práv (z pohl'adu judikatúry a doktríny štrasburských orgánov ochrany práv) II. rozšírené vydanie. Bratislava: EUROKÓDEX, 2006.

9. ŠÁMAL, P., MUSIL, J., KUCHTA, J. et. al.: Trestní právo procesné. 4. přepracované vydání. Prague: C. H. Beck: 2013.

17 Nález Ústavného súdu Slovenskej republiky z 22.9.1999 vydaný pod č. k.: I. ÚS 17/1999. Zbierka nálezov a uznesení Ústavného súdu Slovenskej republiky 1999, p. 365.

18 The explanatory report for the Act on Victims is available at: https://www.slov-lex.sk/legislativne-procesy//SK/dokumenty/LP-2017-551. 
10. ŠÁMAL, P. et. al.: Trestní řád I. § 1 až 156. Komentář. 7th edition Prague. C. H. Beck, 2013.

11. Nález Ústavného súdu Slovenskej republiky z 22.9.1999 vydaný pod č. k.: I. ÚS 17/1999. Zbierka nálezov a uznesení Ústavného súdu Slovenskej republiky 1999, p. 365.

12. The explanatory report for the Act on Victims is available at: https://www.slovlex.sk/legislativne-procesy/-/SK/dokumenty/LP-2017-551.

\section{CONTACT DETAILS OF THE AUTHOR}

\section{JUDr. Martin Štrkolec, PhD.}

Assistant Professor

Pavol Jozef Šafárik University in Košice

Faculty of Law, Department of Criminal Law

Kováčska 26, 04075 Košice

E-mail: martin.strkolec@upjs.sk

Telephone: +421552344147 